\title{
Investigation on the operation status of a user-side thermal facility of Korean district heating system by using exergy analysis method
}

\author{
Chan Lee ${ }^{\mathrm{a}}$, Bo Yeon Chang ${ }^{\mathrm{a} *}$, Hoon Kim ${ }^{\mathrm{b}}$, Hyung Woo Park ${ }^{\mathrm{b}}$, Shin Young \\ $\operatorname{Lim}^{\mathrm{c}}$ \\ ${ }^{a}$ Univ.of Suwon, Wauangil 17, Hwaseong, 445-743, Republic of Korea \\ ${ }^{b}$ Yujin Energy Consulting Co., Anyang, Republic of Korea \\ ${ }^{c}$ Korea District Heating Corp., Seoul, 135-220, Republic of Korea
}

\begin{abstract}
The present study investigates the operation status of a user-side thermal facility where thermal energy is supplied from main Korean district heating system and distributed to many household spaces. On-site measurements are made on the operation conditions of a user-side thermal facility and then exergy analysis method is applied to the measurement results to determine the locations and the magnitudes of exergy loss/destructions. In addition, based on the exergy analysis results, overall exergy efficiency and heat exchanger effectiveness of the user-side thermal facility are calculated.
\end{abstract}

Keywords: User-side thermal facility, exergy analysis, heat exchanger, mixing, exergy efficiency

\section{Introduction}

In Korea, district heating system has been widely distributed and used since the 1990's for residential heating and hot water supply of many households in urban areas. Through the past 30 years' operation of Korean district heating system, remarkable energy saving and efficiency improvements have been achieved and employed to cogeneration power plants producing thermal energy and thermal pipe networks transporting thermal energy to user-side thermal facilities. For this reason, these energy production and distribution systems have been being efficiently operated by the Korean District Heating Corp.(KDHC) as public-sector supplier. However, the most of Korean user-side thermal facilities have not shown any significant technological advance in energy saving because they have been owned and operated by private-sector users. Because this discrepancy in the efforts of energy saving between the supplier- and the user-sides would be major obstacle in constructing overall Korean district heating system as high-efficiency one, there are growing research demands and concerns on high efficiency userside thermal facility from both public- and private-sectors in Korea.

Exergy analysis method has been used as thermodynamic system evaluation tool in many industrial fields such as power, chemical and environmental plants. Bejan et al.[1] introduced and applied exergy concept to gas turbine cogeneration plant. Kotas [2] also applied exergy analysis method to many thermal plant problems. Nakata and Baldvinsson [3] made exergy and exergoeconomic analysis on a residential heat supply system in Japan. Schmidt and Torio [4] applied exergy analysis method to improve the performance of waste heat district heating network. Regarding heat exchange exergy, Wu et al. [5] formulated exergy effectiveness relationships for different type heat exchangers and compared them when NTU and capacity ratio are changed. Pandey and Nema [6] analyzed the exergy loss due heat transfer and

\footnotetext{
* Manuscript received April 8, 2016; revised July 26, 2016.

Corresponding author. Tel.: +82-31-220-2219; E-mail address: clee@ suwon.ac.kr.

doi: $10.12720 /$ sgce.5.3.196-201
} 
fluid friction in plate-type heat exchanger by CFD method. Therefore, based on the previous exergy researches, exergy analysis method is expected to be an effective evaluation tool suitable for analyzing the user-side thermal facility of Korean district heating system.

The present study is conducted to investigate the operation and energy utilization status of a user-side thermal facility of Korea, which is composed of the main components as residential heating, hot water supply heat exchangers, pumps and valves. On-site measurements are made on the operation conditions of each component such as temperature, pressure and mass flow rate, and then exergy analysis method is applied to the measured results. From the present exergy analysis results, the locations and the magnitudes of exergy destruction/loss are determined and overall facility and component exergy efficiencies are calculated. The present exergy analysis results also give guideline for higher thermal efficiency operation of the user-side facility.

\section{Exergy Analysis Method}

\subsection{Description of korean user-side thermal facility}

As shown in Fig. 1, Korean user-side thermal facility is composed of two heat exchanger units for residential heating and hot water supply, which utilize the thermal energy of heat source water supplied from the distribution network of KDHC. The heat source water stream from the KDHC is distributed to two streams for residential heating (HX1) and hot water supply (HX2) heat exchangers in user-side thermal facility to heat up water streams recirculated through households. As can be seen in Fig.1, in residential heating heat exchanger (HX1), some part of supplied water (DHS) is bypassed and mixed with returned water (DHR). Hot water supply heat exchanger (HX2) is installed to reheat the temperature of returned water (HWR) to the supplied water (HWS). It is noted that two heat exchangers used in the Korean facilities are plate-types, and linked at three mixing points (MP1, MP2, MP3). In addition to the above-mentioned heat exchangers, auxiliary components such as pumps, valves and flow meter are equipped on water pipelines in the user-side facility.

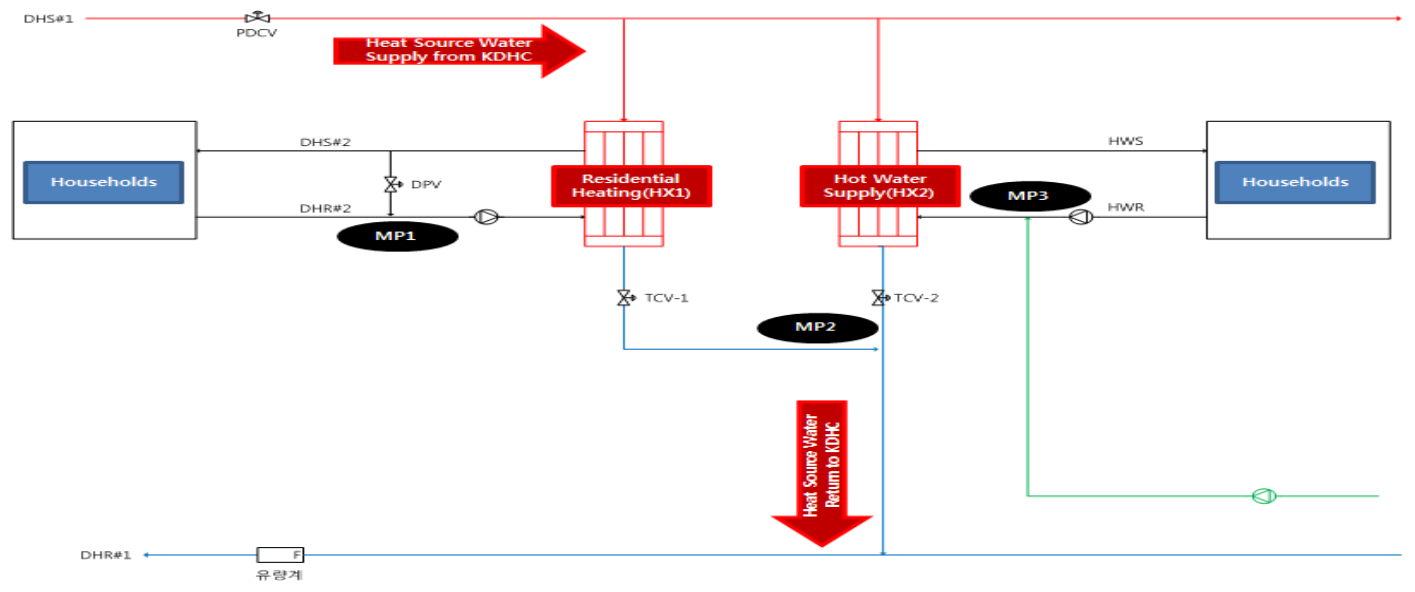

Fig. 1. Process flow diagram of korean user-side thermal facility.

\subsection{Definitions of exergy and its efficiency}

According to the theoretical formulation by $\mathrm{Wu}$ et al. [5], the specific flow exergy $\left(\mathrm{e}_{\mathrm{x}}\right)$ of open system is defined as

$$
e_{x}=h-h_{\infty}-T_{\infty}\left(s-s_{\infty}\right)
$$

where $\Delta \mathrm{p}$ and NTU represent pressure drop and number of transfer unit of heat exchanger, and subscripts $c, h$ represent cold, hot streams of heat exchanger. 
Applying and integrating the equation (1) from inlet to outlet of heat exchanger, total exergy $\operatorname{variation}(\Delta \mathrm{Ex})$ of water fluid for heat exchanger as open system can be determined as

$$
\Delta E_{x}=m C_{p}\left(T_{o}-T_{i}-T_{\infty} \ln \frac{T_{o}}{T_{i}}\right)-m v \Delta p
$$

where $\mathrm{m}, \mathrm{C}_{\mathrm{p}}$, v and $\mathrm{T}$ represent mass flow rate, specific heat and specific volume of water, and subscripts $\mathrm{o}$ and i mean outlet and inlet of heat exchanger.

Referring to Fig. 2, the energy effectiveness $(\varepsilon)$ and the exergy effectiveness $\left(\varepsilon_{\mathrm{e}}\right)$ as heat exchanger performance indices[7] are defined as follows:

$$
\begin{aligned}
\varepsilon & =\frac{T_{h i}-T_{h o}}{T_{h i}-T_{c i}}=\frac{e^{(1-R) N T U_{-1}}}{e^{(1-R) N T U_{-R}}} \\
R & =\frac{\left(C_{p} m\right)_{\min }}{\left(C_{p} m\right)_{\max }}
\end{aligned}
$$

where $\Delta \mathrm{p}$ and NTU represent pressure drop and number of transfer unit of heat exchanger, and subscripts $\mathrm{c}, \mathrm{h}$ represent cold, hot streams of heat exchanger.

Exergy efficiency is generally defined as the ratio of exergy product to exergy fuel $[1,8]$, and the definitions for heat exchanger and mixing element can be found in Fig. 3.

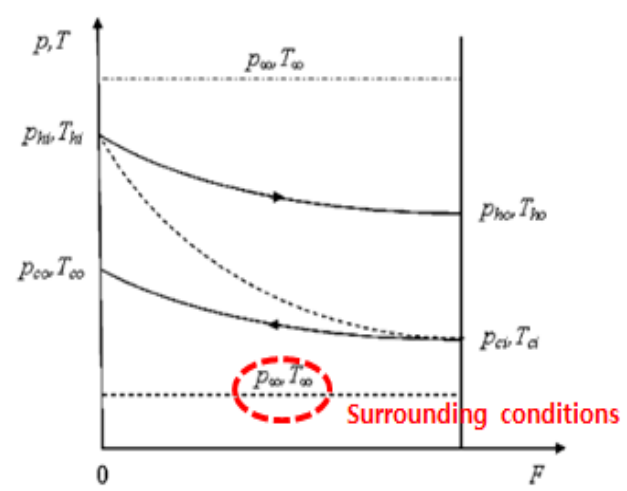

Fig. 2. Typical heat transfer profiles in a heat exchanger.
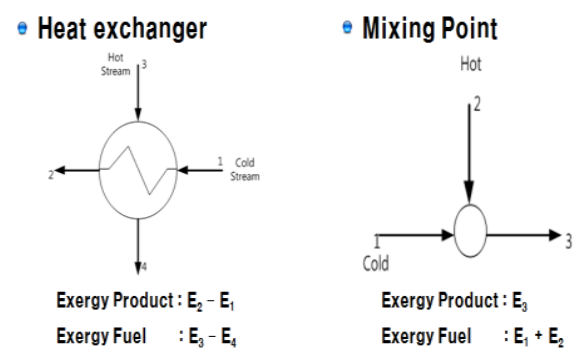

Fig. 3. Definitions of exergy efficiencies of heat exchanger and mixing element.

\section{Exergy Analysis Results}

\subsection{On-site measurements on a Korean user-side thermal facility}

Prior to the exergy analysis on a Korean user-side thermal facility, on-site measurements were conducted on the operation parameters of water streams in the facility, temperature, pressure and mass flow rate. The present measurements were made at the surrounding conditions of $1 \mathrm{~atm}$ and $-15^{\circ} \mathrm{C}$, and 
the measured results are summarized in Fig. 4.

As shown in Fig. 4, in residential heating heat exchanger (HX1), only $0.2 \%$ of supplied water(DHS) is bypassed and the temperature difference between supplied(DHS) and returned(DHR) water streams is set to $14{ }^{\circ} \mathrm{C}$. In hot water supply heat exchanger, the makeup water of $1,920 \mathrm{~kg} / \mathrm{h}$ is supplied and the temperature difference between supplied (HWS) and returned (HWR) water streams is set to $9^{\circ} \mathrm{C}$. The temperature of heat source water supplied from $\mathrm{KDHC}$ is $115^{\circ} \mathrm{C}$.

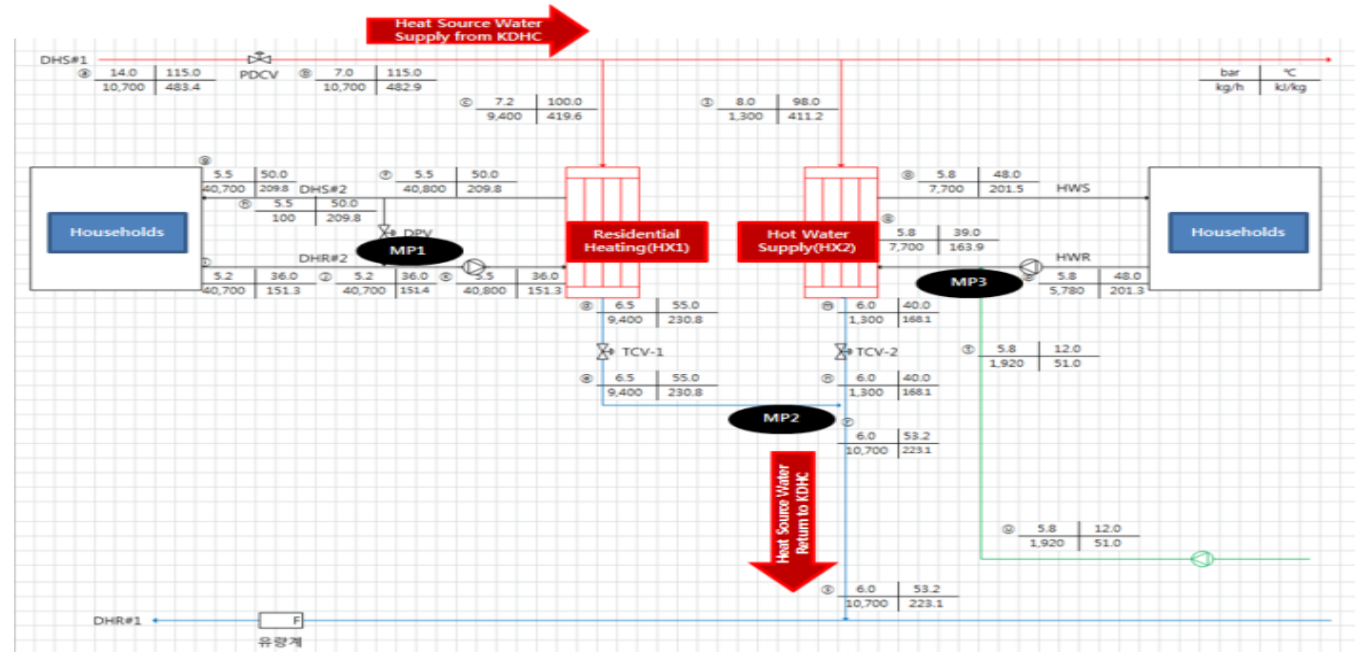

Fig. 4. Measurement data of a Korean user-side thermal facility.

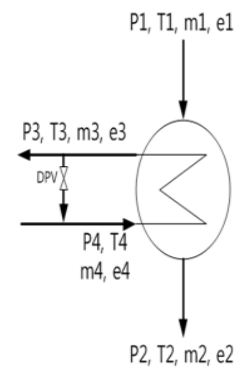

\begin{tabular}{|c|c|c|c|c|}
\hline Descipition & 1 & 2 & 3 & 4 \\
\hline$\underset{\substack{p \\
\text { (bar) }}}{ }$ & 7.2 & 6.5 & 5.5 & 5.5 \\
\hline $\begin{array}{l}T \\
(C)\end{array}$ & 100.0 & 55.0 & 50.0 & 36.0 \\
\hline $\begin{array}{c}\mathrm{m} \\
(\mathrm{kg} / \mathrm{h})\end{array}$ & 9,400 & 9,400 & 40,800 & 40,800 \\
\hline $\begin{array}{l}\text { exergy } \\
(\mathrm{N} / \mathrm{kg})\end{array}$ & 83.97 & 34.30 & 29.87 & 19.15 \\
\hline
\end{tabular}

Fig. 5. Exergy efficiency of HX1.

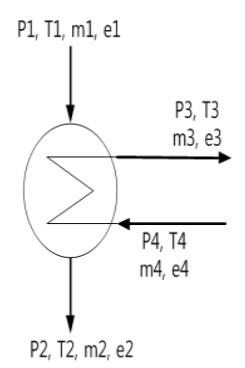

\begin{tabular}{|c|c|c|c|c|}
\hline Desceiption & 1 & 2 & 3 & 4 \\
\hline $\begin{array}{c}p \\
\text { (bar) }\end{array}$ & 8.0 & 6.0 & 5.8 & 5.8 \\
\hline $\begin{array}{c}T \\
(0)\end{array}$ & 98.0 & 40.0 & 48.0 & 39.0 \\
\hline $\begin{array}{c}m \\
(\mathrm{~kg} / \mathrm{h})\end{array}$ & 1,300 & 1,300 & 7,700 & 7,700 \\
\hline $\begin{array}{c}\text { exergy } \\
(\mathrm{NJ} / \mathrm{kg})\end{array}$ & 81.47 & 22.04 & 28.21 & 21.29 \\
\hline
\end{tabular}
- Exergy efficiency : $68.9 \%$
Exergy destruction rate : $23,786 \mathrm{KJ} / \mathrm{h}$

Fig. 6. Exergy efficiency of HX2.

\subsection{Exergy analysis results using measurement data}

Based on the measurement results of Fig. 4, exergy analysis is conducted on each flow element such as heat exchanger, valve or mixing point. In calculating entropy and exergy of water from the measured data, the present study uses the IAPWS formulation [9]. Fig. 5 shows the exergy data of residential heating heat exchanger(HX1), from which the exergy destruction and efficiency are calculated as $29,479 \mathrm{~kJ} / \mathrm{h}$ and 
93.7\%. Fig. 6 also shows the exergy data of hot water supply heat exchanger (HX2), from which the exergy destruction and efficiency are calculated as $23,786 \mathrm{~kJ} / \mathrm{h}$ and $68.9 \%$ Comparing the results of Figs. 5 and 6 , residential heating heat exchanger (HX1) is more efficiently operated than hot water supply heat exchanger(HX2).

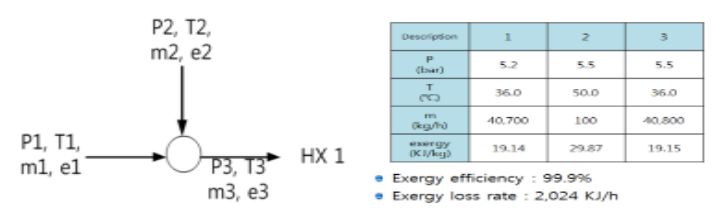

Fig. 7. Exergy efficiency of MP1.

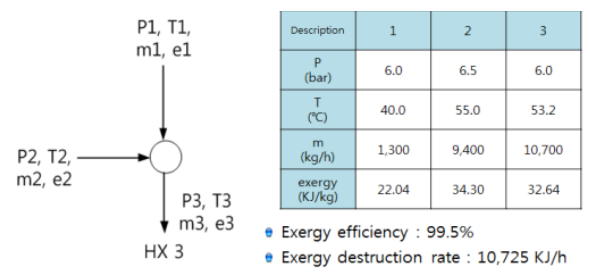

Fig. 8. Exergy efficiency of MP2.
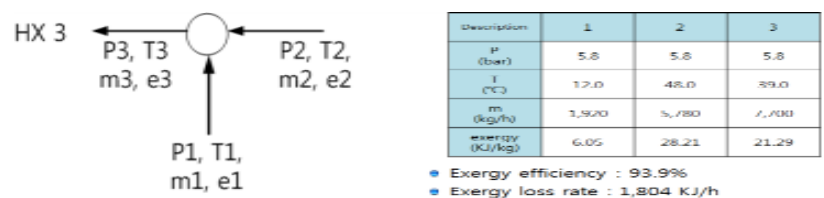

Fig. 9. Exergy efficiency of MP3.

Exergy analysis results on three mixing points are depicted in Fig. 7, Fig. 8 and Fig. 9. From the results of Fig. 7, Fig. 8 and Fig. 9, it can be known that all the mixing points are operated above 90\% exergy efficiency and their exergy losses are much less than the exergy destructions of heat exchangers.

Table 1. Effectiveness and NTU of heat exchanger

\begin{tabular}{|c|c|c|c|}
\hline Description & Energy Effectiveness(\%) & NTU & Exergy Effectiveness(\%) \\
\hline HX 1 & 21.9 & 0.2536 & 16.5 \\
\hline HX 2 & 15.3 & 0.1677 & 11.3 \\
\hline
\end{tabular}

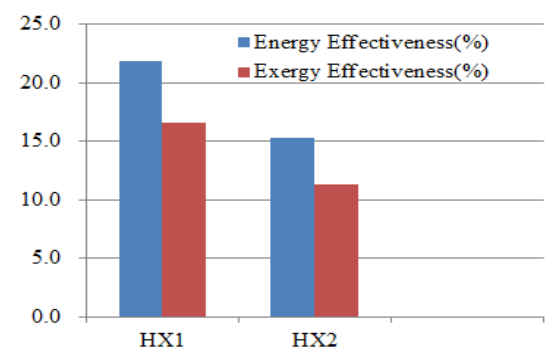

Fig. 10. Effectivenesses of heat exchangers.

Table 1 and Fig. 10 summarizes the energy, the exergy effectiveness and the NTU of heat exchangers, and shows all the heat exchangers are operated at low energy/exergy effectiveness and NTU of 15 22\%, $11 \sim 17 \%$ and $0.17 \sim 0.25$. These low performances of heat exchangers can be explained from the heat exchange process operating with low temperature difference between supplied and returned water streams. 


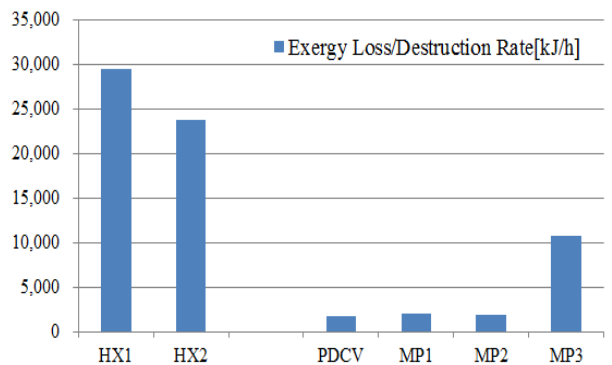

Fig. 11. Exergy destruction/loss of flow elements.

Fig. 11 shows the exergy destruction/loss rates of elements in the present thermal facility, and overall exergy input, destruction and efficiency are summarized in Table. 2. The main exergy destruction sources are heat exchangers, and accordingly overall facility exergy efficiency is reduced to $67.4 \%$.

Table 2. Total exergy and overall exergy efficiency

\begin{tabular}{|c|c|c|}
\hline Total Exergy Input $(\mathrm{KJ} / \mathrm{h})$ & Total Exergy Loss \& Destruction $(\mathrm{KJ} / \mathrm{h})$ & Overall Facility Exergy Efficiency $(\%)$ \\
\hline 561,460 & 183,036 & 67.40 \\
\hline
\end{tabular}

\section{Conclusions}

Exergy analysis method is developed and applied to a user-side thermal facility of Korean district heating system. Exergy analysis results show that residential heating and hot supply water heat exchangers are operated with big exergy destruction while mixing elements being operated with very small exergy loss. The energy and the exergy effectiveness of heat exchangers are between 15 22\% and $11 \sim 17 \%$. Due to less energy saving operations of heat exchangers, the overall exergy efficiency of userside facility is reduced to $67.4 \%$. In addition, from the present analysis results, it is expected that higher efficiency of user-side facility can be achieved through the heat exchange operation with higher supplyreturn water temperature difference.

\section{Acknowledgements}

The authors wish to thank the research grant from Korea District Heating Corp.(KDHC).

\section{References}

[1] Bejan A, Tsatsaronis G, Moran M. Thermal Design \& Optimization. John Wiley \& Sons, Inc.; 1996.

[2] Kotas TJ. The Exergy Method of Thermal Plant Analysis. Exergon Publishing Company; 1985.

[3] Baldvinsson I, Nakata T. A comparative exergy and exergoeconomic analysis of a residential heat supply system paradigm of Japan and local source based district heating system using SPECO(specific exergy cost) method. Energy, 2014; 74:537-554.

[4] Torio H, Scmidt D. Development of system concepts for improving the performance of a waste heat district heating network with exergy analysis. Energy and Buildings, 2010; 42:1601-1609.

[5] Wu SY, Yuan X, Li Y, Xiao L. Exergy transfer effectiveness on heat exchanger for finite pressure drop. Energy, 2007; 32:2110-2120.

[6] Pandey SD, Nema VK. Analysis of heat transfer, friction factor and exergy loss in plate heat exchanger using FLUENT. Energy and Power, 2011; 1(1):6-13.

[7] Hewitt GF, Shires GL, Bott TR. Process Heat Transfer. Begellhouse; 1994.

[8] Li JY, Lee C. The analysis on exergy loss and its reduction methods in steam desuperheating and depressurizing process. The KSFM Journal of Fluid Machinery, 2015;18(6):19-26.

[9] Revised Release on the IAPWS Industrial Formulation 1997, IAPWS, 2007. 